Терапевтична стоматологія

удК 616.314.17-008.1-085-092.001.8

DOI 10.11603/2311-9624.2020.4.11720

СЮ. Ю. Яров

Донецький національний медичний університет МОЗ України

e-mail: Kaf.stomatologii2@ukr.net

\title{
Сучасні принципи і засоби медикаментозного лікування при генералізованому пародонтиті (огляд літератури)
}

\section{ІНФОРМАЦІЯ}

Надійшла до редакції/Received: 10.11.2020 p.

Ключові слова: генералізований пародонтит; медикаментозне лікування; принципи лікування; медикаментозні засоби.

\section{АНОТАЦІЯ}

Резюме. Лікування генералізованого пародонтиту базується на принципах комплексного підходу з урахуванням індивідуальних особливостей стоматологічного та соматичного статусу, превалювання дії тих чи інших місцевих і загальних пародонтопатогенних факторів у кожній конкретній клінічній ситуації. Етіотропне лікування передбачає проведення раціональної загальної і місцевої антимікробної терапії з метою елімінації пародонтопатогенних бактерій і блокади запального каскаду з продукцією прозапальних цитокінів, ейкозаноїдів, матриксних металопротеїназ і т. д. Патогенетичне лікування спрямоване на купірування провідних ланок розвитку захворювання. Обгрунтованим є призначення нестероїдних протизапальних засобів; застосування екзогенних інгібіторів матриксних металопротеїназ; імунокоригуюча терапія; цитокінотерапія; застосування антиоксидантів; призначення препаратів для стимулювання процесу формування кістки. Правильна спрямованість етіопатогенетичного медикаментозного лікування підтверджена численними даними літератури про їх високу клінічну ефективність. Однак актуальними залишається розробка диференційованих підходів до вибору комплексу медикаментозних засобів загального та місцевого застосування залежно від екзо- й ендопародонтопатогенних факторів, які найбільше впливають на патогенез генералізованого пародонтиту.
Вступ. Відповідно до сучасних уявлень, лікування генералізованого пародонтиту базується на принципах комплексного підходу 3 урахуванням індивідуальних особливостей стоматологічного та соматичного статусу, превалювання дії тих чи інших місцевих i загальних пародонтопатогенних факторів у кожній конкретній клінічній ситуації. Комплексне лікування включає застосування терапевтичних, хірургічних, ортопедичних, ортодонтичних, фізіотерапевтичних втручань, загальних і місцевих медикаментозних засобів. Загальне і місцеве медикаментозне лікування повинно мати етіотропну, патогенетичну й симптоматичну спрямованість.

Етіотропне медикаментозне лікування генералізованого пародонтиту

Етіотропне лікування передбачає проведення раціональної загальної (за суворими показаннями) і місцевої антимікробної терапії $з$ метою елімінації пародонтопатогенних бактерій та блокади запального каскаду з продукцією прозапальних цитокінів, ейкозаноїдів, матриксних металопротеїназ і т. д. Необхідною умовою для проведення раціональної антимікробної терапії при генералізованому пародонтиті є виділення і моніторна ідентифікація мікроорганізмів дентальної біоплівки 3 визначенням їх чутливості до антибактеріальних препаратів [1, 2]. Пріоритетне значення має місцева антимікробна терапія із застосуванням найбільш визнаних у клінічній пародонтології препаратів - 0,05-0,3 \% розчину хлоргексидину, 0,02 \% розчину декаметоксину, 1 \% розчину діоксидину, 1 \% водного розчину йодинолу, 0,25 \% розчину хлорофіліпту та ін. у вигляді інстиляцій у пародонтальні кишені, аплікацій, зрошень, ротових ванно- 
чок, в складі лікувальних пародонтальних пов'язок [3]. Показаннями до системного застосування антибіотиків є: ГП II, III ступенів, загострений перебіг (множинні пародонтальні абсцеси); атипові «агресивні» форми пародонтиту - локалізований і генералізований ювенільний пародонтит; швидкопрогресуючий пародонтит дорослих; резистентний до лікувальних впливів (рефрактерний) пародонтит; симптоматичний виразково-некротичний гінгівіт; підготовка до пародонтальної хірургії; у пацієнтів груп ризику (кардіоваскулярні порушення, цукровий діабет, імунодефіцит і т. д.) [4]. Проведене клініко-лабораторне дослідження з вивчення ефективності препарату «Ципролет А» в комплексному лікуванні хворих на генералізований пародонтит I-II ступенів на тлі цукрового діабету показало, що препарат володіє вираженою антимікробною дією - на 40 \% зменшує мікробне заселення ротової порожнини та зникають патогенні мікроорганізми і дріжджоподібні гриби [5]. В даний час унаслідок обмеженої можливості проведення бактеріологічних досліджень вибір антибактеріального препарату, дозування і тривалість його прийому визначаються в основному емпірично і за клінічним ефектом. У вітчизняній і зарубіжній літературі є повідомлення щодо терапевтичної ефективності при лікуванні генералізованого пародонтиту наступних препаратів: лінкоміцину, метронідазолу, тетрацикліну, доксицикліну, клафорану, сумамеду, руліду, ципрофлоксацину, фузидин-натрію і ін. [6]. Однак, як показують клініко-лабораторні дослідження, обраний препарат не завжди адекватно впливає на мікрорганізми пародонтальної кишені й ротової порожнини в цілому, що, у свою чергу, не тільки не полегшує стан хворого, але і призводить до суттєвих порушень мікробіоценозу зниження факторів місцевої і загальної імунологічної реактивності, дефіциту або елімінації облігатної мікрофлори ротової порожнини [7]. Крім того, унаслідок нераціонального, часто безконтрольного і масового застосування антибіотиків при величезній швидкості розмноження бактерій і удосконаленні їх захисних механізмів відбувається пришвидшена селекція резистентних штамів i, отже, зниження ефективності використовуваних препаратів. При проведенні антибактеріального лікування при генералізованому пародонтиті повинні суворо дотримуватися таких принципів: наявність показань для призначення ан- тимікробних засобів; встановлення причин, що перешкоджають проведенню ефективної антимікробної терапії; ідентифікація мікроорганізмів і визначення чутливості мікробів до препаратів; вибір оптимальних схем лікування з урахуванням локалізації інфекційного процесу або виду патогенних бактерій; раціональна комбінація антимікробних засобів; вибір оптимального способу призначення та оптимальної дози лікарського препарату; визначення тривалості антимікробної терапії. Необхідно зазначити, що на відміну від значної ефективності системних антибіотиків, ні для жодного мікрорганізму не було виявлено вірогідного зниження його вмісту після використання бактеріофагів [1]. При визначенні чутливості виділених при генералізованому пародонтиті штамів аеробних, факультативних і анаеробних бактерій до антибіотиків встановлено, що найбільш ефективними щодо всього спектра мікрофлори пародонтальної кишені є амоксиклав, доксициклін, кліндаміцин, цефотаксим, ципрофлоксацин і офлоксацин. Серед антимікотиків найбільшу активність щодо дріжджоподібних грибів роду Candida i Cryptococcus neoformans, які часто зустрічаються при ГП, проявляють флуконазол та ітраконазол. Застосування кліндаміцину (далацин Ц) у хворих із загостреним перебігом ГП II, III ступеня тяжкості сприяє швидкому поліпшенню клінічної картини, викликає повне зникнення або різке зниження частоти виділення і рівня заселення мікрофлори пародонтальної кишені [8].

Патогенетичне медикаментозне лікування генералізованого пародонтиту

У плані патогенетичного лікування, спрямованого на купірування провідних ланок розвитку захворювання, обгрунтованим є призначення нестероїдних протизапальних засобів (переважно селективних інгібіторів ЦОГ-2 - для зниження рівня простагландину $\mathrm{E}_{2}$ ) [9], застосування екзогенних інгібіторів матриксних металопротеїназ [10], імунокоригуюча терапія, яка передбачає застосування засобів, що стимулюють імунні процеси, і специфічно активують імунокомпетентні клітини (Т- і В-лімфоцити) й додаткові фактори імунітету (макрофаги, секреторні імуноглобуліни, цитокіни та ін.) [11], цитокінотерапія, яка включає призначення препаратів конкретних цитокінів або препаратів антагоністів цитокінів IЛ-1, ФНП, препаратів інтерферону (лаферон, імунерон), індукторів інтерферону (амізон, аміксин) 
[12], застосування антиоксидантів прямої дії, що входять безпосередньо в структуру антиоксидантної системи (токофероли, аскорбінова кислота, поліфеноли, $\beta$-каротин) і непрямої діï, що підвищують антиокиснювальний потенціал тканин (препарати есенціальних фосфоліпідів, попередники піридиннуклеотидів, глутатіону) [13] призначення препаратів для стимулювання процесу формування кістки (альфакальцидол, альфа-Д_-Тева, Кальцій-Д Нікомед, іприфлавон) [14]. Досить обгрунтованим є застосування в комплексному лікуванні генералізованого пародонтиту неспецифічних протизапальних засобів (НП33) [15]. Вони мають протизапальну, жарознижувальну і болезаспокійливу дії унаслідок пригнічення синтезу ферменту циклооксигенази (ЦОГ), в результаті чого у вогнищі запалення знижується вироблення високоактивних біогенних речовин - ендоперекисів, простагландинів, тромбоксану. Препарати в основному діють на фазу ексудації (гальмування синтезу простагландинів призводить до зменшення гіперемії, набряку, болю; синтезу тромбоксану - до нормалізації мікроциркуляції; до зниження активності гіалуронідази та кількості медіаторів запалення - гістаміну, серотоніну, кінінів, норадреналіну) і проліферації (зниження активності фібробластів і зменшення синтезу колагену). Однак деякі препарати (індометацин, ортофен, ацетилсаліцилова кислота), знижуючи рівень вільних радикалів, що утворюються в процесі синтезу простагландинів, діють на фазу альтерації [16]. При лікуванні захворювань пародонта НПЗ3 широко застосовуються для місцевого медикаментозного лікування. Відомий досвід застосування 3 \% ацетилсаліцилової мазі, 3 \% ортофенової мазі, 1 \% емульгель вольтарену (Швейцарія) і 1 \% крему піроксикаму (Росія) в складі пародонтальних пов'язок, лікувальної пасти з диклофенаком натрію, гелю з флубіпрофеном, полоскання ротової порожнини 0,1% розчином кеторолаку і 1,5 \% розчином дексибупрофену, зубної пасти, що містить 1 і 3 \% кетопрофену [17]. У комплексному лікуванні генералізованого пародонтиту знайшли своє застосування селективні інгібітори ЦОГ-2 - це клас НПЗ3, які вибірково діють на індуцибельну цОГ-2 i, тим самим практично виключають побічні явища, що виникають при дії на фізіологічну ЦОГ-1 (з боку шлунково-кишкового тракту, нирок, кровоносної та ендокринної систем). Це такі препарати, як еторикоксиб, рофекок- сиб, целекоксиб, мелоксикам, німесулід, етодолак і т. д. [18]. Запропоновано схеми місцевого (імобілізувати на сорбенті «Ентеросгель) і загального застосування селективного інгібітора ЦОГ-2 - мелоксикаму («Мелбек»), Туреччина - при лікуванні генералізованого пародонтиту без супутньої соматичної патології та на тлі цукрового діабету другого типу [19].

3 розвитком концепції про роль вільнорадикального окиснення в патогенезі пародонтиту та визначенням функції антиоксидантної системи, постійно ведеться пошук і створення нових лікарських засобів для профілактики і лікування захворювань пародонта, що включають антиоксиданти прямої і непрямої дії. Пріоритетним є застосування природних антиоксидантів, або біоантиоксидантів, - речовин рослинного і тваринного походження, повністю позбавлених побічних ефектів [20]. Серед них особливе місце займають рослинні поліфеноли, які поряд з каталазою і аскорбіновою кислотою, відіграють основну роль у системі антиоксидантного захисту пародонта. До поліфенолів відносять фенольні сполуки, в ароматичному кільці яких $€$ дві й більше гідроксильних груп. Виділяють моноциклічні (кавова, галова та ін. кислоти), біциклічні (ресвератрол), трициклічні (флавоноїди) і тетрациклічні (глікозиди флавоноїдів) з'єднання [21]. Найчисленнішу і найбільш вивчену групу рослинних поліфенолів представляють флавоноїди (або біофлавоноїди) біологічно активні речовини, що володіють Р-вітамінною активністю [22]. Головним в механізмі біологічної дії флавоноїдів $€$ їх антиоксидантні властивості, які проявляються здатністю пригнічувати ксантиноксидазу (основний генератор супероксидного радикала), а також безпосередньо здійснювати захоплення супероксидних радикалів. Крім виражених антиоксидантних властивостей вони володіють різноманітністю біологічних функцій, серед яких - протизапальна дія, антипроліферативні властивості, остеотропна активність, естрогеноподібні ефекти й ін. [23]. У експериментах на тваринах показано, що при недостатньому аліментарному надходженні рослинних поліфенолів відбувається розвиток деструктивних змін в пародонті, зумовлених процесами вільнорадикального окиснення [24]. 3 недостатністю надходження рослинних поліфенолів також пов'язують порушення фізіологічної проліферативної активності (темпу проліферації, поновлення) епітеліального 
пласта слизової оболонки ротової порожнини, в тому числі й покривного епітелію ясен i, як наслідок, зниження його резистентності до патогенних агентів [25]. Серед біофлавоноїдів найбільшого поширення при лікуванні захворювань пародонта отримав кверцетин. Клінічні дослідження різних авторів встановили, що препарат «Кверцетин» в гранулах (Борщагівський ХФЗ), отриманий з флавоноїдного глікозиду рутину або бутонів софори японської, при системному (перорально по 1 г 3-4 рази на день) і місцевому (у вигляді $20 \%$ гелю для аплікацій на ясна й інстиляцій у пародонтальні кишені) застосуванні у хворих на генералізований пародонтит має виражений лікувальний ефект на тканини пародонта [26]. Показано, що використання кверцетину в комплексному лікуванні пародонтиту сприяє ліквідації запального вогнища, нормалізує стійкість капілярів ясен (за показниками вакуумної проби за Кулаженком), знижує вміст перекисних продуктів (дієнових і трієнових кон'югатів у крові ясен, малонового діальдегіду - в крові й тканинах ясен, у ротовій рідини), підвищує загальну антиокиснювальну активність і активність церулоплазміну в тканинах пародонта. Відома здатність кверцетину пригнічувати фосфоліпазу А2, що призводить до зниження проникності біомембран і визначає його мембраностабілізуючу дію [27]. Це підтверджується зниженням рівня арахідонової кислоти і її похідних (лейкотрієнів С4 і тромбоксанів В2) в ясенній крові хворих на генералізований пародонтит після застосування кверцетину. Інгібування ліпооксигенази є одним з механізмів протизапальної дії препарату. Безсумнівний інтерес для клінічної пародонтології представляє препарат «Біотрит» із зеленого листя пшениці, який виготовляють за оригінальною технологією НПА «Одеська біотехнологія» і Інститут стоматології та щелепно-ліцевої хірургії АМН України спільно з Інститутом очних хвороб і тканинної терапії імені В. П. Філатова АМН України. Препарат містить вітаміни $\mathrm{P}, \mathrm{U}$, групи $\mathrm{B}\left(\mathrm{B}_{1}, \mathrm{~B}_{2}, \mathrm{~B}_{3}, \mathrm{~B}_{6}\right)$, макро- і мікроелементи, аміно- й органічні кислоти, високоактивні пептиди, а також флавоноїди кемпферол і трицин. Саме з наявністю даних флавоноїдів пов'язують виражену антиоксидантну дію біотриту, яка проявляється зниженням рівня малонового діальдегіду і дієнових кон'югатів, а також підвищенням активності антиоксидантних ферментів (супероксиддисмутази, глутатіон-пероксидази і глутатіон-редуктази) в ротовій рідині при лікуванні хворих на хронічний катаральний гінгівіт і генералізований пародонтит [28]. Показано, що препарат виявляє адаптогенні, протизапальні, антиоксидантні й мембранотропні властивості, наявність яких не залежить від способу введення - місцевого (у вигляді аплікацій), перорального (в пігулках), парентерального (підшкірні ін'єкції ампульного розчину) [29].

Отримані дані про суттєві зміни в системі місцевого імунітету ротової порожнини і тканин пародонта, а також суперечливі дані про динаміку показників системного імунітету у хворих на генералізований пародонтит є підставою для застосування препаратів цілеспрямованої місцевої імуномодулюючої дії і системного призначення препаратів адаптогенної дії. Виділяють імуномодулятори мікробного походження, що містять ліпополісахаридні комплекси («Продигіозан», «Пірогенал»), бактеріальні рибосоми в комбінації 3 протеогліканами мембран («Рибомуніл»), лізати бактерій (IPC-19, «Бронхомунал») [11]. Показана висока терапевтична ефективність препарату «Імудон», призначеного для проведення місцевої специфічної імунотерапії, який складається з суміші очищених лізатів бактерій і грибів, що найчастіше ініціюють патологічні процеси ротової порожнини. Встановлено, що препарат має стимулюючу дію на специфічні й неспецифічні фактори гуморального імунітету - це підтверджується достовірним підвищенням вмісту лізоциму і секреторного імуноглобуліну А в ротовій рідині у хворих на генералізований пародонтит після курсу імудону [30]. Особливе місце серед імуномодулюючих препаратів займають фітоадаптогени. Так, проведеними клініко-імунологічними дослідженнями виявлено виражену імуномодулюючу дію адаптогену на основі біотриту «Біотрит-Дента» на показники як місцевого, так і системного імунітету у хворих на генералізований пародонтит, що дозволяє рекомендувати його для комплексного медикаментозного лікування при генералізованого пародонтиту різного ступеня тяжкості [31].

Встановлений факт участі матриксних металопротеїназ (ММП) в деструкції тканин пародонта вказує на необхідність застосування при лікуванні генералізованого пародонтиту ïx екзогенних інгібіторів. Такими інгібіторами в пародонтології зарекомендували себе доксициклін та хімічно модифікований те- 
трациклін, які в основному застосовуються в субантимікробних дозах у формах для місцевого застосування (тетрациклінові нитки, доксициклін-гель) [32]. Отримано дані, що окремі види катехінів зеленого чаю - епікатехін галлат і епігаллокатехін галлат - інгібують активність ММП-2, ММП-9 і ММП-12, а також активують профермент ММП-2 [33]. Корейські вчені серед 100 рослин, які використовуються в корейській народній медицині, відібрали екстракт кори в’яза (Ulmi macrocarpa) і його активний компонент олігомер проціанідин. Проведені дослідження з використанням желатинової зимографії показали, що екстракт кори в’яза й олігомер проціанідин в концентраціях 100-10000 мг/мл надавали виражену інгібуючу дію: на металопротеїнази в ясенній рідині (ММП-8 і ММП-9), взятих із пародонтальних кишень, глибиною більше 6 мм у дорослих пацієнтів із пародонтитом; на профермент ММП-2 і активну форму ММП-2 (після активації пародонтопатогенними бактеріями Treponema lecithinolyticum) в культурі клітин періодонтальної зв'язки; а також на трипсиноподібні бактеріальні протеази, які продукують Treponema denticola i Porphyromonas gingivalis, які, у свою чергу, здатні активувати різні ММП. У всіх випадках активність олігомера проціанідину перевищувала активність екстракту кори в'яза, який містить 20 \% олігомеру [34].

Отримані клініко-лабораторні результати обстеження пацієнтів свідчать про клінічну ефективність застосування комплексу адреноблокаторів для лікування хворих на генералізований пародонтит з проявами психосоматичного стресу [35].

Значне місце в патогенетичному медикаментозному лікуванні генералізованого пародонтиту займає остеотропна терапія. У літературі досить широко висвітлені питання механізмів деструктивно-резорбтивного процесу в альвеолярній кістці в осіб різного віку і статі, 3 різною системною патологією, при якій розвиваються порушення структурно-функціонального стану кісткової тканини скелета, показана роль системних порушень метаболізму кісткової тканини в розвитку і прогресуванні генералізованого пародонтиту, обгрунтовані схеми диференційованого застосування остеотропних препаратів. Серед препаратів для стимулювання процесу формування кістки теоретично обгрунтовані і знайшли застосування активні метаболіти вітаміну D (альфакальцидолу, альфа-D патит («Остеогенон»), комплексний препарат «Кальцій-D -Нікомед», іприфлавон - «Остеохін» [36]. Однак як показує практичний досвід, представлені остеотропні препарати рідко призначають лікарі через обмежену можливість проведення необхідного моніторингу концентрації гормонів, кальцію та інших компонентів у крові й сечі, наявності побічних ефектів і протипоказань. У зв'язку з чим, більш доцільним є застосування препаратівбіорегуляторів: «Віталонг» - комплекс антиоксидантів ( $\alpha$-токоферол, $\beta$-каротин, аскорбінова кислота) і лецитину; ЕКСО - екстракт сої, що містить ізофлавони сої (геністеїн, дайдзеїн у глікозидній формі), вітаміни групи В, макроі мікроелементи, а також інгібітор трипсину «Кунітца»; ІФСО - ізофлавони сої в агліконовій формі й «Біотрит-Дента» - препарат на основі біотріту (екстракту із зеленого листя пшениці) 3 введенням глюконату кальцію, фториду натрію, лецитину, декаметоксина, аскорбінової і лимонної кислоти. Застосування даної групи препаратів забезпечує у хворих на генералізований пародонтит посилення темпу формування кістки альвеолярного відростка і поліпшення її якості шляхом регуляції адаптаційно-трофічних систем організму (прооксидантно-антиоксидантної, протеазно-інгібіторної й ін.) та нейроендокринної функції [8].

Висновки. Сучасні підходи до медикаментозного лікування хворих на генералізований пародонтит базуються на купіруванні провідних ланок етіопатогенезу захворювання. Правильна спрямованість вказаної тактики підтверджена численними даними літератури про високу клінічну ефективність запропонованих і впроваджених схем медикаментозного лікування при генералізованому пародонтиті. Однак актуальними залишаються питання уточнення ключових механізмів розвитку і перебігу захворювання в кожному конкретному клінічному випадку, зокрема розробка диференційованих підходів до вибору комплексу медикаментозних засобів загального та місцевого застосування залежно від екзо- й ендопародонтопатогенних факторів, які найбільше впливають на патогенез генералізованого пародонтиту. 
(СЮ. Ю. Яров

Донецкий национальный медицинский университет МО3 Украины

\title{
Современные принципы и средства медикаментозного лечения при генерализованном пародонтите (обзор литературы)
}

\begin{abstract}
Резюме. Лечение генерализованного пародонтита базируется на принципах комплексного подхода с учетом индивидуальных особенностей стоматологического и соматического статуса, превалирования действия тех или общих пародонтопатогенных факторов в каждой конкретной клинической ситуации. Этиотропное лечение предполагает проведения рациональной общей и местной антимикробной терапии с целью элиминации пародонтопатогенных бактерий и блокады воспалительного каскада с продукцией противовоспалительных цитокинов, эйкозаноидов, матриксных металлопротеиназ и т. д. Патогенетическое лечение направленно на купирование ведущих звеньев развития заболевания. Обоснованным является назначение нестероидных противовоспалительных средств; применение экзогенных ингибиторов матриксных металлопротеиназ; иммунокоригирующая терапия; цитокинотерапия; применение антиоксидантов; назначение препаратов для стимулирования процесса формирования кости. Правильная направленность этиопатогенетического медикаментозного лечения подтверждена многочисленными данными литературы об их высокой клинической эффективности. Однако актуальной остается разработка дифференцированных подходов к выбору комплекса медикаментозных средств общего и местного применения в зависимости от экзо- и эндопародонтопатогенных факторов, которые наиболее влияют на патогенез генерализованного пародонтита.
\end{abstract}

Ключевые слова: генерализованный пародонтит; медикаментозное лечение; принципы лечения; медикаментозные средства.

\author{
(C)Yu. Yu. Yarov \\ Donetsk National Medical University
}

\section{Modern principles and methods of drug treatment in cases of generalized periodontitis (literature review)}

Summary. Treatment of generalized periodontitis is based on the principles of the integrated approach, taking into account the individual characteristics of dental and somatic status, the prevalence of certain local and general periodontal factors in each clinical situation. Etiotropic treatment involves rational general and local antimicrobial therapy to eliminate periodontal pathogenic bacteria and block the inflammatory cascade with the production of proinflammatory cytokines, eicosanoids, matrix metalloproteinases, etc. Pathogenetic treatment is aimed at alleviating the leading links in the development of the disease. The prescription of nonsteroidal anti-inflammatory drugs, use of exogenous inhibitors of matrix metalloproteinases; immunocorrective therapy; cytokine therapy; use of antioxidants; appointment of drugs to stimulate the process of bone formation are justified. The correct direction of etiopathogenetic drug treatment is confirmed by numerous data from the literature on its high clinical efficacy. However, the development of differentiated approaches to the choice of drugs for general and local use depending on exo- and endoparodontopathogenic factors, that influence the pathogenesis of generalized periodontitis most, still remains relevant.

Key words: generalized periodontitis; drug treatment; principles of treatment; drugs.

\section{СПИСОК ЛІТЕРАТУРИ}

1. Закиров Т. В. Системная антимикробная терапия в комплексном лечении обострения генерализованого агрессивного пародонтита / Т. В. Закиров, Е. С. Ворошилина, И. А. Госьков // Клиническая стоматология. - 2019. - № 2. - С. 35-39.

2. Loesche W. J. The diagnosis and treatment of anaerobic periodontal infection / W. J. Loesche // Infect. Med. - 2008. - Vol. 15 (11). - P. 788-797.
3. Минкин Л. Н. Применение хлоргексидинсодержащих препаратов для лечения заболеваний пародонта / Л. Н. Минкин, Ю. П. Евглевкая // Пародонтология. - 2007. - № 4 (6). - С. 29-33.

4. Батіг В. М. Лікування загостреного перебігу генералізованого пародонтиту у хворих з переважанням симпатичної нервової системи / В. М. Батіг // Сучасна стоматологія. - 2018. - № 1. - С. 37-39. 
5. Білоклицька Г. Ф. Клінічна ефективність стоматологічного NBF Gingival Gel при лікуванні пацієнтів із запальними захворюваннями пародонту / Г. Ф. Білоклицька, О. В. Решетняк, К. О. Гороголь // Сучасна стоматологія. - 2020. - № 3. - С. 33-38.

6. Сидельникова Л. Ф. Обоснование и оценка эффективности системной антибактериальной терапии генерализованного пародонтита у пациентов с сахарным диабетом / Л. Ф. Сидельникова, И. Г. Дикова, С. М. Захарова // Сучасна стоматологія. - 2020. - № 3. - С. 28-33.

7. Пашаев А. Ч. Анализ факторов риска воспалительных заболеваний пародонта / А. Ч. Пашаев, В. М. Гасанов, С. Т. Гусейнова // Современная стоматология. - 2020. - № 1. - С. 39-41.

8. Чумакова Ю. Г. Патогенетичне обгрунтування методів комплексного лікування генералізованого пародонтиту (клініко-експериментальне дослідження) : автореф. дис. ... д-ра мед. наук : 14.01.22 / Ю. Г. Чумакова ; Ін-т стом. АМН України. - Одеса, 2007. - 39 c.

9. Використання Тантум Верде в лікуванні виразкового гінгівіту / К. Є. Печковський, О. Ф. Несін, I. М. Печковська [та ін.] // Сучасна стоматологія. 2020. - № 2. - C. 20-24.

10. Ramamurthy N. S. Inhibition of matrix metalloproteinase-meduated periodontal bone loss in rats a comparison of 6 chemically modified tetracyclines / N. S. Ramamurthy, B. R. Rifkin, R. A. Greenwald // J. Periodontol. - 2002. - Vol. 73. - P. 726-734.

11. Шульженко А. Д. Клініко-лабораторна ефективність лікування жінок із захворюванннями пародонта на тлі бактеріального вагінозу / А. Д. Шульженко, Т. О. Петрушанко, М. В. Микитюк // Український стоматологічний альманах. - 2018. № 1. - С. 35-39.

12. Соколова I. І. Клініко-імунологічні показники у хворих на генералізований пародонтит при лікуванні аміксином / I. І. Соколова // Вісник стоматолоriii. - 2005. - № 4. - С. 35-38.

13. Рагимов Ч. Р. Лечебно-профилактические особенности заболеваний пародонта у больных гипотиреозом / Ч. Р. Рагимов, Т. Г. Гусейнова, Л. А. Алиева // Сучасна стоматологія. - 2020. - № 1. - С. 34-39.

14. Поширеність та інтенсивність захворювань тканин пародонта в осіб молодого віку на тлі первинного гіпотиреозу / О. М. Репецька, М. М. Рожко, Н. В. Скрипник, О. М. Ільницька // Сучасна стоматологія. -2020. - № 1. - С. 42-48.

15. Salvi G. E. The effect of nonsteroidal antiinflammatory drugs (selective and nonselective) on the treatment of periodontal diseases / G. E. Salvi, N. P. Lang // Curr. Pharm. Des. - 2005. - Vol. 11 (14). - P. 1757-1769.

16. Мельничук Г. Н. Цитокиновый профиль слюны у больных генерализованным пародонтитом / Г. Н. Мельничук // Современная стоматология. 2013. - № 1. - С. 35-40.

17. Сечко О. Н. Сравнительная эффективность нестероидных противовоспалительных средств в комплексном лечении заболеваний пародонта / О. Н. Сечко // Стоматология. - 2008. - № 3. - С. 22-24. 18. Насонов Е. Л. Ингибиторы циклооксигеназы-2: современная концепция / Е. Л. Насонов // Терапевтический архив. - 2009. - № 11. - С. 54-57.
19. Саноян В. В. Оцінка ефективності лікування хронічного генералізованого пародонтиту у хворих на цукровий діабет типу 2 шляхом застосування фізичних та імунологічних показників ротової рідини: автореф. дис. ... канд. мед наук : 14.01.22 / В. В. Саноян ; ВДНЗ «УМСА». - Полтава, 2013. - 21 с. 20. Савєльєва Н. М. Результати комплексного лікування генералізованого пародонтиту I-II ступенів тяжкості хронічного перебігу на тлі токсокорозу / Н. М. Савєльєва // Вісник наукових досліджень. 2017. - № 1. - С. 112-116.

21. Левицкий А. П. Роль полифенолов пищи в формировании местной неспецифической резистентности тканей ротовой полости / А. П. Левицкий, О. Н. Воскресенский, С. В. Носийчук // Вісник стоматології. - 2005. - № 3. - С. 2-8.

22. Борисенко А. В. Особливості лікування захворювань пародонту в жінок, які приймають оральні контрацептиви / А. В. Борисенко, Т. В. Ватанха // Coвременная стоматология. - 2018. - № 5. - С. 24-27.

23. Левицкий А. П. Фитоэстрогены (биохимия, фармакология, применение в медицине) / А. П. Левицкий, О. А. Макаренко, О. И. Сукманский. - Одесса : «Моряк», 2002. - 95 с.

24. Назарян Р. С. Прооксидантно-антиоксидантний баланс у крові і тканинах пародонта щурів при хронічній дії незбалансованого фактичного раціону / Р. С. Назарян, Ю. В. Нікітченко // Одеський медич. журнал. - 2004. - № 6 (86). - С. 12-13.

25. Воскресенский О. Н. Влияние хронического эмоционально-болевого стресса и прооксиданта делагила на состояние эпителия ротовой полости у крыс с недостаточностью полифенолов / О. Н. Воскресенский // Вісник стоматології. - 2005. - № 2. C. 7-11.

26. Ярова С. П. Ефективність методу диференційної корекції перекисного окислення ліпідів і антиоксидантного захисту в комплексному лікуванні генералізованого пародонтиту / С. П. Ярова, Т. С. Осипенкова // Вісник стоматології. - 2001. - № 1. - С. 28-31. 27. Lindabe M. Selective inhibition of group II phospholipase A2 by quercetin / M. Lindabe, C. Tagasson // Inflammation. - 2003. - Vol. 17 (5). - P. 573-582.

28. Волик Н. А. Влияние биогенных стимуляторов экстракта алоэ и биотрита - на процессы пероксидации липидов в слюне при воспалительных заболеваниях пародонта / Н. А. Волик // Укр. біохімічний журн. - 2009. - Т. 71, № 5. - С. 90-93.

29. Тілігузова Н. А. Клініко-лабораторне обгрунтування диференційованого застосування препаратів-адаптогенів рослинного походження в комплексному лікуванні хворих на хронічний катаральний гіншгівіт і генералізований пародонтит : автореф. дис. ... канд. мед наук : 14.01.22 / Н. А. Тілігузова ; Ін-т стом. АМН України. - Одеса, 2002. - 19 с.

30. Глазунов О. А. Оцінка предикторів довготривалого ефекту комплексного лікування пародонтиту у хворих на ревматоїдний артрит / О. А. Глазунов, Л. В. Крячкова, Д. В. Фесенко // Вісник стоматології. 2019. - Т. 34, № 4 (109). - С. 11-16.

31. Чумакова Ю. Г. Обоснование применения растительных полифенолов в комплексном лечении генерализованного пародонтита / Ю. Г. Чумакова // Вісник стоматології. - 2006. - № 3 (53). - С. 41-52. 
32. Choi D. H. Effects of subantimicrofial dose doxycycline therapy on crevicular fluid MMP-8 and gingival tissue MMP-9, TIMP-1 and IL-6 levels in chronic periodontitis / D. H. Choi // J. Periodont. Res. - 2004. Vol. 39. - P. 20-26.

33. Demeule M. Matrix metalloproteinase inhibition by green tea catechins / M. Demeule // Biochim. Biophis. Acta. - 2000. - No. 1478. - P. 51-60.

34. Inhibitory effect of procianidin oligomer from elm cortex on the matrix metalloproteinases and proteases of periodontopathogens / S.-E. Song, B.-K. Choi, S.-N. Kim [et al.] // J. Periodont. Res. - 2003. - Vol. 38. - P. 282-289. 35. Кононова О. В. Ефективність лікування загостреного перебігу генералізованого пародонтиту у хворих з проявами психоемоційного стресу / О. В. Кононова // Сучасна стоматологія. - 2020. - № 2. - С. 24-29. 36. Омарова Х. О. Характеристика плотности костной ткани челюстей в динамике лечения пародонтита «Остеогеноном» / Х. О. Омарова, Н. Г. Дмитриева // Пародонтология. - 2004. - № 4 (33). - С. 16-19.

\section{REFERENCES}

1. Zakirov, T.V., Voroshilina, E.S., \& Goskov, I.A. (2019). Sistemnaya antimikrobnaya terapiya v kompleksnom lechenii obostreniya generalizovanogo agressivnogo parodontita [Systemic antimicrobial therapy in the complex treatment of exacerbation of generalized aggressive periodontitis]. Klinicheskaya stomatologiya Clinical Dentistry, 2, 35-39 [in Russian].

2. Loesche, W.J. (2008). The diagnosis and treatment of anaerobic periodontal infection. Infect. Med., 15, (11), $788-797$.

3. Minkin, L.N., \& Evglevkaia, Yu.P. (2007). Primenenie khlorgeksidin soderzhashchih preparatov dlya lecheniya zabolevanii parodonta [The use of chlorhexidine-containing drugs for the treatment of periodontal diseases]. Parodontologiya-Periodontology, 4 (6), 29-33 [in Russian].

4. Batig, V.M. (2018). Likuvannia zahostrenoho perebihu heneralizovanoho parodontytu u khvoryh $\mathrm{z}$ perevazhanniam sympatichnoi nervovoi systemy [Treatment of acute generalized periodontitis in patients with a predominance of the sympathetic nervous system]. Suchasna stomatologiya - Modern Dentistry, 1, 37-39 [in Ukrainian].

5. Biloclitska, G.F., Reshetniak, O.V., \& Gorogol, K.O. (2020). Klinichna efektyvnist stomatolohichnoho NBF Gingival Gel pry likuvanni patsiientiv iz zapalnymy zakhvoriuvanniamy parodontu [Clinical efficacy of dental NBF Gingival Gel in the treatment of patients with inflammatory periodontal disease]. Suchasna stomatologiya - Modern Dentistry, 3, 33-38 [in Ukrainian].

6. Sidelnikova, L.F., Dikova, I.G., \& Zaharova, S.M. (2020). Obosnovanie i otsenka effektivnosti sistemnoy antibakterialnoy terapii generalizovannogo parodontita $\mathrm{u}$ patsientov s sakharnym diabetom [Substantiation and evaluation of the effectiveness of systemic antibacterial therapy of generalized periodontitis in patients with diabetes mellitus]. Sovremennaya stomatologiya - Modern Dentistry, 3, 28-33 [in Russian].

7. Pashaev, A.Ch., Gasanov, V.M., \& Guseinova, S.T. (2020). Analiz faktorov riska vospalitelnykh zabolevaniy parodonta [Analysis of risk factors for inflammatory periodontal diseases]. Sovremennaya stomatologiya Modern Dentistry, 1, 39-41 [in Russian].

8. Chumakova, Yu.G. (2007). Patohenetychne obhruntuvannia metodiv kompleksnoho likuvannia heneralizovanoho parodontytu (klinikoeksperymentalne doslidzhennia) [Pathogenetic substantiation of methods of complex treatment of generalized periodontitis (clinical and experimental study)]. Doctor's thesis. Odesa [in Ukrainian].

9. Pechkovskiy, K.E., Nesin, O.F., Pechkovskaia, I.M., Timoxina, T.O., Viderska, G.V., \& Shkred, O.G. (2020). Vykorystannia Tantum Verde v likuvanni vyrazkovoho hinhivitu [The use of Tantum Verde in the treatment of ulcerative gingivitis]. Suchasna stomatolohiia - Modern Dentistry, 2, 20-24 [in Ukrainian].

10. Ramamurthy, N.S., Rifkin, B.R., \& Greenwald, R.A. (2002). Inhibition of matrix metalloproteinase-meduated periodontal bone loss in rats a comparison of 6 chemically modified tetracyclines. J. Periodontol, 73, 726 - 734. 11. Shuljenko, A.D., Petrushanko, T.O., \& Mikituk, M.V. (2018). Kliniko-laboratorna efektyvnist likuvannia zhinok iz zakhvoriuvannniamy parodonta na tli bakterialnoho vahinozu [Clinical and laboratory effectiveness of treatment of women with periodontal diseases on the background of bacterial vaginosis]. Ukrainskyi stomatolohichnyi almanakh - Ukrainian Dental Almanac, 1, 35-39 [in Ukrainian].

12. Sokolova, I.I. (2005). Kliniko-imunolohichni pokaznyky u khvorykh na heneralizovanyi parodontyt pry likuvanni amiksynom [Clinical and immunological parameters in patients with generalized periodontitis during treatment with amixin]. Visnyk stomatolohii Bulletin of Dentistry, 4, 35-38 [in Ukrainian].

13. Ragimov, Ch.R., Guseinova, T.G., \& Alieva, L.A. (2020). Lechebno-profilakticheskie osobennosti zabolevanii parodonta u bolnykh hipotireozom [Therapeutic and prophylactic features of periodontal disease in patients with hypothyroidism]. Sovremennaya stomatolohii Modern Dentistry, 1, 34-39 [in Russian].

14. Kepecka, O.M., Royko, M.M., Skripnik, N.V., \& Ilnicka, O.M. (2020). Poshirenist ta intensivnist zakhvoriuvan tkanyn parodonta $\mathrm{v}$ osib molodoho viku na tli pervynnoho hipotyreozu [Prevalence and intensity of periodontal diseases in young people on the background of primary hypothyroidism]. Suchasna stomatologiya - Modern Dentistry, 1, $42-48$ [in Ukrainian].

15. Salvi, G.E., \& Lang, N.P. (2005). The effect of nonsteroidal antiinflammatory drugs (selective and nonselective) on the treatment of periodontal diseases. Curr. Pharm. Des., 11 (14), 1757-1769.

16. Melnichuk, G.N. (2013). Tsytokinovyi profil sliuny $\mathrm{u}$ bolnykh heneralizovannym parodontytom [The cytokine profile of saliva in patients with generalized periodontitis]. Sovremennaya stomatologiya - Modern Dentistry, 1, 35-40 [in Russian].

17. Sechko, O.N. (2008). Sravnitelnaya effektivnost nesteroidnykh protivovospalitelnykh sredstv v 
kompleksnom lechenii zabolevaniy parodonta [Comparative efficacy of non-steroidal antiinflammatory drugs in the complex treatment of periodontal diseases]. Stomatologiya - Dentistry, 3, 22 -24 [in Russian].

18. Nasonov, E.L. (2009). Ingibitory tsiklooksigenazy-2: sovremennaya kontseptsiya [Cyclooxygenase-2 inhibitors: a modern concept]. Terapevticheskiy arkhiv - Therapeutic Archive, 11, 54-57 [in Russian].

19. Sanoian, V.V. (2013). Otsinka efektyvnosti likuvannia khronichnoho heneralizovanoho parodontytu u khvoryh na tsukrovyi diabet 2 typu shliakhom zastosuvannia fizychnykh ta imunolokhichnykh pokaznykiv rotovoi ridyny [Evaluation of the effectiveness of treatment of chronic generalized periodontitis in patients with type 2 diabetes mellitus by using physical and immunological parameters of oral fluid]. Candidate's thesis. Poltava [in Ukrainian].

20. Saveleva, N.M. (2017). Rezultaty kompleksnoho likuvannia heneralizovanoho parodontytu I-II stupeniv tiazhkosti khronichnoho perebihu na tli toksokorozu [Results of complex treatment of generalized periodontitis of I-II degrees of severity of chronic course against toxocariasis]. Visnyk naukovykh doslidzhen - Bulletin of Scientific Researches, 1, 112-116 [in Ukrainian].

21. Leviczkii, A.P., Voskresenskii, O.N., \& Nosiychuk, S.V. (2005). Rol polifenolov pishchi $\mathrm{v}$ formirovanii mestnoy nespecificheskoy rezistentnosti tkaney rotovoy polosti [The role of food polyphenols in the formation of local nonspecific resistance of the tissues of the oral cavity]. Visnyk stomatolohii -Dentistry Bulletin, 3, 2-8 [in Russian].

22. Borisenko, A.V., \& Vatanha, T.V. (2018). Osoblyvosti likuvannia zakhvoriuvan parodontu $\mathrm{v}$ zhinok, yaki priimaiut oralni kontratseptyvy [Peculiarities of treatment of periodontal disease in women who use oral contraceptives]. Sovremennaya stomatologiya Modern Dentistry, 5, 24-27 [in Ukraninan].

23. Leviczkii, A.P., Makarenko, O.A., \& Sukmanskii, O.I. (2002). Fitoestrogeny (biokhimiya, farmakologiya, primeneniye v meditsine), [Phytoestrogens (biochemistry, pharmacology, medical applications)]. "Moryak" - "Sailor", 95 [in Russian].

24. Nazarian, P.S., \& Nikitchenko, Yu.V. (2004). Prooksidantno-antioksidantnyi balans u krovi i tkanynakh parodonta shchuriv pry khronichnii dii nezbalansovanoho faktychnoho ratsionu [Prooxidantantioxidant balance in blood and periodontal tissues of shchuyv in chronic conditions of unbalanced actual race]. Odeskyi medych. zhurnal - Odesa Medical Journal, 6 (86), 12-13 [in Ukrainian].

25. Voskresenskiy, O.N. (2005). Vliyanie khronicheskogo emotsionalno-bolevogo stressa i prooksidanta delagila na sostoyanie epiteliya rotovoi polosti u krys s nedostatochnostyu polifenolov [Influence of chronic emotional pain stress and Delagil prooxidant on the state of the oral epithelium in rats with polyphenol deficiency]. Visnyk stomatolohii - Dentistry Bulletin, 2, 7-11 [in Russian].

26. Yarova, S.P., \& Osipenkova, T.S. (2001). Efektyvnist metodu diferentsiinoi korektsii perekysnoho okyslennia lipidiv i antyoksydantnoho zahystu v kompleksnomu likuvanni heneralizovanoho parodontytu [The effectiveness of the method of differential correction of lipid peroxidation and antioxidant treatment in complex treatment of generalized periodontitis]. Visnyk stomatolohii - Dentistry Bulletin, 1, 28-31 [in Ukrainian]. 27. Lindabe, M., \& Tagasson, C. (2003). Selective inhibition of group II phospholipase A2 by quercetin. Inflammation, 17 (5), 573-582.

28. Volik, N.A. (2009). Vliyanie biogennykh stimulyatorov - ekstrakta aloe i biotrita - na protsessy peroksidatsii lipidov v slyune pri vospalitelnykh zabolevaniyakh parodonta [Influence of biogenic stimulants - aloe extract and biotrite - on the processes of lipid peroxidation in saliva in inflammatory periodontal diseases]. Ukr. biokhimichnyi zhurn. - Ukrainian Biological Journal, 71 (5), 90-93 [in Russian].

29. Tiliguzova, N.A. (2002). Kliniko-laboratorne obhruntuvannia dyferentsiiovanoho zastosuvannia preparativ-adaptoheniv roslynnoho pokhodzhennia v kompleksnomu likuvanni khvorykh na khronichnyi kataralnyi hinhivit i heneralizovanyi parodontyt [Clinical laboratory priming of the differentiated preservation of adaptogen preparations of the herb in the complex treatment of patients with chronic catarrhal gingivitis and generalization of periodontitis]. Candidate's thesis. Odesa [in Ukrainian].

30. Glazunov, O.A., Kriachkova, L.V., \& Fesenko, D.V. (2019) Otsinka predyktoriv dovhotryvaloho efektu kompleksnoho likuvannia parodontytu u khvorykh na revmatoidnyi artryt [Assessment of predictors of the pre-treated complex treatment of periodontitis in patients with rheumatoid arthritis]. Visnyk stomatolohii - Dentistry Bulletin, 4 (109), 34, 11-16 [in Ukrainian].

31. Chumakova, Yu.G. (2006). Obosnovanie primeneniya rastitelnyh polifenolov $\mathrm{v}$ kompleksnom lechenii generalizovannogo parodontita [Rationale for the use of plant polyphenols in the complex treatment of generalized periodontitis]. Visnyk stomatolohii - Dentistry Bulletin, 3 (53), 41-52 [in Russian].

32. Choi, D.H. (2004). Effects of subantimicrofial dose doxycycline therapy on crevicular fluid MMP-8 and gingival tissue MMP-9, TIMP-1 and IL-6 levels in chronic periodontitis. J. Periodont. Res, 39, 20-26.

33. Demeule, M. (2000). Matrix metalloproteinase inhibition by green tea catechins. Biochim. Biophis. Acta, 1478, 51-60.

34. Song, S.-E., Choi, B.-K., Kim, S.-N., Yoo, Y.-J., Kim, M.M., Park, S.-K., ..., \& Kim, C.-K. (2003). Inhibitory effect of procianidin oligomer from elm cortex on the matrix metalloproteinases and proteases of periodontopathogens. J. Periodont. Res, 38, 282-289.

35. Cononova, O.V. (2020). Efektyvnist likuvannia zahostrenoho perebihu heneralizovanoho parodontytu $\mathrm{u}$ khvorykh z proiavamy psykhoemotsiinoho stresu [Efficiency of treatment of aggravated generalized periodontitis in ailments with manifestations of psychomotive stress]. Suchasna stomatolohiia - Modern Dentistry 2, 24-29 [in Ukrainian].

36. Omarova, H.O., \& Dmitrieva, N.G. (2004). Kharakteristika plotnosti kostnoy tkani chelyustei v dinamike lecheniya parodontita "Osteogenonom» [Characteristics of the density of the jaw bone tissue in the dynamics of treatment of periodontitis with "Osteogenon"]. Parodontologiya - Periodontology, 4 (33), 16-19 [in Russian]. 